\title{
Aberrant Gut-To-Brain Signaling in Irritable Bowel Syndrome - The Role of Bile Acids
}

OPEN ACCESS

Edited by:

Maria Cecilia Giron,

University of Padua, Italy

Reviewed by:

Valentina Caputi,

University College Cork, Ireland

Rachelle Irwin,

Ulster University, United Kingdom Jose Emilio Mesonero,

University of Zaragoza, Spain

*Correspondence:

Dervla O'Malley

d.omalley@ucc.ie

Specialty section:

This article was submitted to

Gut Endocrinology,

a section of the journal

Frontiers in Endocrinology

Received: 21 July 2021 Accepted: 04 November 2021 Published: 30 November 2021

Citation:

Ni Dhonnabháín R, Xiao Q and O'Malley D (2021) Aberrant Gut-To-

Brain Signaling in Irritable Bowel Syndrome - The Role of Bile Acids.

Front. Endocrinol. 12:745190. doi: $10.3389 /$ fendo.2021.745190

\author{
Róisín Ní Dhonnabháín ${ }^{1}$, Qiao Xiao ${ }^{1,2}$ and Dervla O'Malley ${ }^{1,2 *}$ \\ ${ }^{1}$ Department of Physiology, College of Medicine and Health, University College Cork, Cork, Ireland, ${ }^{2}$ APC Microbiome \\ Ireland, University College Cork, Cork, Ireland
}

Functional bowel disorders such as irritable bowel syndrome (IBS) are common, multifactorial and have a major impact on the quality of life of individuals diagnosed with the condition. Heterogeneity in symptom manifestation, which includes changes in bowel habit and visceral pain sensitivity, are an indication of the complexity of the underlying pathophysiology. It is accepted that dysfunctional gut-brain communication, which incorporates efferent and afferent branches of the peripheral nervous system, circulating endocrine hormones and local paracrine and neurocrine factors, such as host and microbially-derived signaling molecules, underpins symptom manifestation. This review will focus on the potential role of hepatic bile acids in modulating gut-to-brain signaling in IBS patients. Bile acids are amphipathic molecules synthesized in the liver, which facilitate digestion and absorption of dietary lipids. They are also important bioactive signaling molecules however, binding to bile acid receptors which are expressed on many different cell types. Bile acids have potent anti-microbial actions and thereby shape intestinal bacterial profiles. In turn, bacteria with bile salt hydrolase activity initiate the critical first step in transforming primary bile acids into secondary bile acids. Individuals with IBS are reported to have altered microbial profiles and modified bile acid pools. We have assessed the evidence to support a role for bile acids in the pathophysiology underlying the manifestation of IBS symptoms.

Keywords: TGR5, FXR, lithocholic acid, microbiome, IBS, bile salt hydrolase 


\section{INTRODUCTION}

Over a hundred trillion microbial organisms, mostly bacteria, inhabit the human colon and have co-evolved with their hosts to have diverse, but primarily beneficial, functions. They scavenge additional calories by fermenting non-digestible foods, secrete vitamins and ensure normal physiological development. A plethora of studies have demonstrated that microbes have the capacity to modulate host physiological homeostasis and have been linked with cognitive disorders such as anxiety, depression, Parkinson's disease, autism spectrum disorder and schizophrenia $(1,2)$, in addition to the development of inflammatory bowel disease (3) and irritable bowel syndrome (IBS) (4). Several direct and indirect mechanisms of cross-barrier communication have been proposed, where microbial, endocrine or immune factors are posited as inter-kingdom signaling molecules (5-7). In this review however, we will focus on bile acids, liver-derived bioactive host molecules that exhibit an interdependency with resident intestinal bacteria.

Hepatocytes synthesize and secrete the primary bile acids, cholic acid (CA) and chenodeoxycholic acid (CDCA), into the duodenum via the biliary ductal system. Comprising about half of the total solutes in bile, their amphipathic structure facilitates emulsification and subsequent digestion and absorption of dietary lipids being emptied from the stomach (8). The enterohepatic circuit is an extremely efficient method whereby $~ 95 \%$ of bile acids are reabsorbed in the terminal ileum and returned via the portal vein to the liver, where they are taken up by hepatocytes and resecreted into the bile ducts. Just $5 \%$ of bile acids escape reuptake and spill over into the colon, the intestinal site with the highest density of microbes. A dynamic, symbiotic relationship exists between microbes and bile acids (Figure 1), resulting in a great diversity of microbially-modified secondary bile acids (9). Bile salt hydrolaze (BSH)-containing bacteria hydrolyze and deconjugate taurine or glycine from the sterol core of the primary bile acids, facilitating further passive reabsorption in the colon. This process also enables further microbially-mediated transformations to produce a plethora of secondary bile acids, including deoxycholic acid (DCA) and lithocholic acid (LCA). This results in an enrichment of secondary bile acids in the colon, where their chemical characteristics help shape bacterial profiles within the microbiome (10). Given that many different cell types express bile acid receptors (11-14) and both active and passive transport of bile acids across the gut barrier and subsequent uptake into the portal vein distributes bile acids to extra-intestinal peripheral organs, bile acids are classified as bioactive signaling molecules (15). We have examined the potential role of bile acids to modify host physiological homeostasis, with a focus on gut-brain axis signaling and their potential role in IBS-related bowel dysfunction.

\section{INTESTINAL PROFILE OF BILE ACIDS}

Biliary secretions are comprised of bile salts, pigments, water, and waste products, including bilirubin and excess cholesterol. In humans, the primary bile acids, CA and CDCA are synthesized and conjugated with either glycine or taurine (16) and stored, concentrated and acidified in the gall bladder prior to being released into the duodenum, along with pancreatic enzyme secretions. Bile acids comprise a family of closely related acidic sterols with similar, but not identical chemical structures and detergent performance. Conjugation of bile acids alters their $\mathrm{pKa}$ meaning bile salts are almost always in a protonated form in the duodenum, thereby restricting their passive movement through the small intestinal epithelial barrier. Apical sodium-dependent bile salt (ABST) transporters in the distal ileum facilitate active transport across the gut barrier prior to their return to the liver via the portal vein. The $\sim 5 \%$ of bile acids which reach the colon, are either reabsorbed via passive diffusion or lost in the feces (17).

Bile acid metabolism is influenced by bacteria with BSH activity, a property that is unique to gut-residing bacteria and may have evolved through host-driven selection (18). An incentive for bacterial participation in this interaction may be the acquisition of the glycine and taurine conjugates for their own metabolic needs, in addition to the disposal of excess electrons generated during fermentation processes (19). Moreover, tolerance of bile may confer an advantage to these microbes in terms of their ability to colonize gut regions (20). In addition to acting as a nutrient source for intestinal bacteria and providing environmental cues, bile acids are also noted for their antimicrobial properties either through direct cytotoxicity (21) or by stimulating innate immune mechanisms (22). This constrains small intestinal bacterial overgrowth (23). Diarrhea resulting from exposure to high levels of bile acids in the colon, may be part of the innate immune response to protect the intestinal epithelium from cytotoxic bile acids, such as LCA (24).

In a bi-directional arrangement, bacterial enzymes chemically modify bile acids, and in turn, bile acids modify gut bacterial profiles. Cleavage of amino acid side chains on glycine- or taurine-conjugated primary bile acids changes their physiochemical properties, such that they are more lipophilic and susceptible to further modification by bacteria, including $7 \alpha-$ dehydroxylation, dehydrogenation and epimerization $(21,25$, 26). Secondary bile acids, such as DCA and LCA, may undergo further modification, including sulphation and glucuronidation, imparting changes in their lipophilicity and hydrophilicity. Moreover, the potency of secondary bile acids for bile acid receptors differs from primary bile acids (23) and the amphipathic nature of bile acids can directly affect the physical properties of cellular lipid membranes, thereby modifying cell signal transduction (27). This has consequences for local signaling and gut homeostasis (28).

\section{MOLECULAR MECHANISMS UNDERLYING BILE ACID SIGNALING}

Given the diversity of bile acids identified in mammals and the variety of bile acid receptors with variable binding affinities and response potencies, it is no surprise that the bioactive functions 


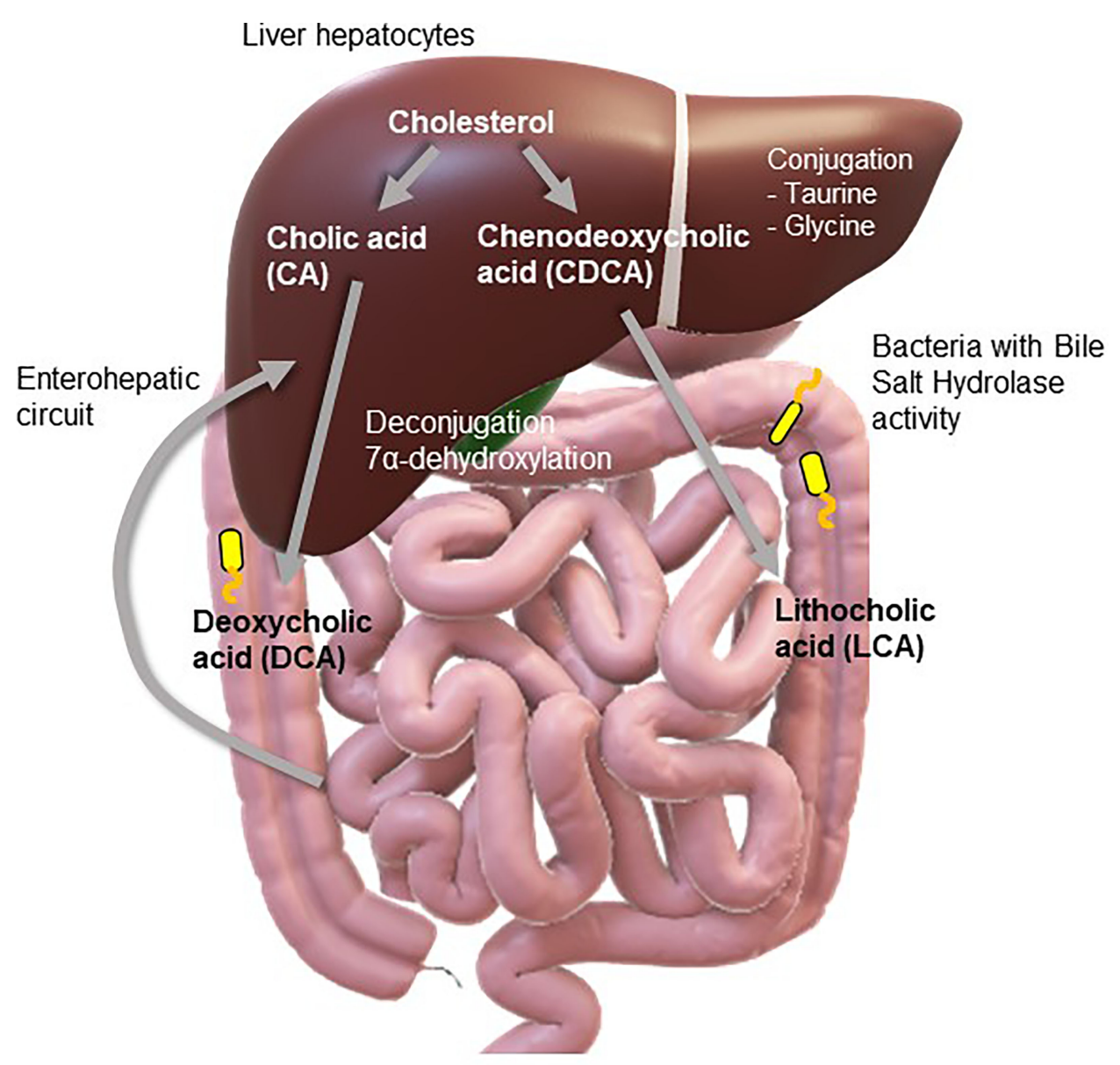

FIGURE 1 | Bile acid synthesis. A dynamic relationship exists between microbes and bile acids with both modifying the profiles of the other. Liver hepatocytes synthesize primary bile acids (cholic acid and chenodeoxycholic acid) from cholesterol. It may then be conjugated within the hepatocytes with taurine or glycine. After bile flows into the intestine, it encounters bile salt hydrolaze (BSH)-containing bacteria, which transform cholic acid and chenodeoxycholic acid into secondary bile acids such as deoxycholic acid (DCA) and lithocholic acid (LCA). A plethora of secondary bile acids are produced through deconjugation of the amino acids, glycine or taurine, and dehydroxylation, dehydrogenation, and epimerization of the cholesterol core. Secondary bile acids returned to the liver by the enterohepatic circuit can also be conjugated to taurine or glycine. Moreover, amino acids may also be conjugated to bile acids further increasing the diversity of human bile acids.

of bile acids differ significantly. Farnesoid X (FXR) is the most extensively studied nuclear bile acid receptor, for which CDCA is the most potent agonist (15), however there are also other bile acid-sensitive nuclear receptors, such as pregnane X (PXR) and vitamin $\mathrm{D}$ receptors (VDR), which are expressed on several different cells types (11-14, 29-31). To activate nuclear bile acid receptors, bile acids must cross cellular and nuclear lipid bilayers, a process that can occur by passive diffusion or be facilitated by active transport $(15,32,33)$. FXR is translocated to the cell nucleus upon activation, where it forms a heterodimer with retinoid $\mathrm{X}$ receptor and binds to hormone response elements present on DNA (34), instigating changes in gene regulation. One of the primary functions of FXR activation by bile acids is the feedback inhibition of bile acid synthesis through the suppression of CYP7A1, the rate-limiting enzyme in the classical bile acid synthesis pathway. Mice lacking FXR exhibit bile acid dyshomeostasis and metabolic disorders (35).
Other nuclear receptors may also be activated by bile acids, although higher concentrations are often required, indicating that they may be more relevant under pathological conditions. PXR is a promiscuous transcription factor important in the metabolism of xenobiotics. It is stimulated by pharmacological reagents, environmental toxicants, bacterial metabolites and the secondary bile acid, LCA. Consistent with a role under pathological conditions, activation of PXR downregulates bacteria which metabolize bile acids and thereby modify bile acid homeostasis (36). In addition to 1,25-dihydroxy vitamin $\mathrm{D}_{3}$ and certain dietary ligands, LCA acts as endogenous ligands for VDR (37), a classic nuclear receptor that mediates several biological functions mainly related to calcium homeostasis and bone maintenance. Similar to FXR, ligand-induced activation of VDR facilitates interaction with retinoid X receptor and DNA binding (37). VDR is highly expressed throughout the digestive tract, where 
it has been found to induce expression of CYP3A and the multidrug resistance-associated protein-3 (37, 38), two enzymes known to metabolize toxic LCA, preventing its reuptake and ensuring excretion in the feces (39).

Bile acids also bind to membrane expressed G-ProteinCoupled Bile Acid Receptor 1 (GPBAR1), also called Takeda G-protein-coupled receptor 5 (TGR5) (40). TGR5 is a member of the G-protein-coupled receptor family, which promotes cyclic adenosine monophosphate (cAMP) synthesis by adenylate cyclase upon activation. This subsequently activates the protein kinase-A pathway, thereby inducing the expression of its target genes (40). LCA is the most potent natural agonist of TGR5, which is expressed at high levels in the liver and intestinal tissue (40), but is also found in many other tissue types. Both conjugated and unconjugated bile acids bind to TGR5, with secondary bile acids, LCA and DCA being most potent (40). Functionally, TGR5 activation is associated with glucose metabolism, neuronal function, immune system control and liver regeneration (41). Other membrane receptors such as sphingosine 1-phosphate receptor (S1PR2) (42) and fibronectin receptor ( $\alpha 5 \beta 1$ integrin) (43) are also activated by bile acids to stimulate intracellular signaling. Cytosolic ileal lipid binding proteins bind to intracellular bile acids, shuttling them to heteromeric OST $\alpha$-OST $\beta$ transporters, which efficiently export them to the portal circulation. To a lesser extent, multidrug resistance-associated protein-3 basolaterally exports native and modified (glucuronidated or sulphated) bile acids from the enterocyte (44).

\section{IRRITABLE BOWEL SYNDROME}

IBS is a clinically diverse disorder, with a multifactorial etiology. Global prevalence varies from $\sim 1 \%$ to more than $45 \%$, with between 5-10\% reported for Europe, the United States and China (45). IBS is the most widespread gastrointestinal disorder in the western world (46). Characterized by chronic, recurrent visceral pain and discomfort, individuals with IBS can be categorized according to predominant bowel habits. Subtypes include IBS with constipation (IBS-C), IBS with diarrhea (IBS-D), mixed or alternating IBS and unsubtyped phenotypes (46). In addition to genetic, epigenetic (47), immunological (48), gender differences (49) and food hypersensitivity $(50,51)$ being reported in individuals with IBS, an increased prevalence of adverse life events and comorbid mood disorders such as anxiety, depression and somatoform disorders $(52,53)$ are also common. It is generally accepted that dysfunction of the bi-directional gutbrain signaling axis contributes to symptom manifestation (54, 55). Indeed, chronic activation of the hypothalamic-pituitaryadrenal (HPA) stress axis has been identified in individuals with IBS $(52,56)$.

TABLE 1 | Clinical studies investigating bile acid levels and microbial profiles in IBS.

\begin{tabular}{|c|c|c|c|}
\hline & Bile acid profiles & IBS Symptoms & Microbial profiles \\
\hline Duboc et al. (57) & $\begin{array}{l}\text { Levels of fecal primary bile acids } \\
\text { were elevated in IBS-D patients } \\
(n=14) \text {. }\end{array}$ & $\begin{array}{l}\text { Primary bile acid levels were correlated with stool } \\
\text { consistency and frequency. }\end{array}$ & $\begin{array}{l}\text { Changes in bacterial profiles were detected in IBS-D. } \\
\text { Some of the changes related to bacteria with a role in } \\
\text { bile acid transformation. }\end{array}$ \\
\hline Shin et al. (58) & $\begin{array}{l}\text { Levels of fecal unconjugated } \\
\text { primary bile acids were elevated } \\
\text { in IBS-D ( } n=31) \text {. } \\
\text { Fecal LCA was elevated in IBS-C } \\
\text { patients }(n=30 \text { ) }\end{array}$ & $\begin{array}{l}\text { Total levels of unconjugated bile acids were } \\
\text { correlated to IBS phenotype (stool number and } \\
\text { form). The correlation was stronger in IBS-D as } \\
\text { compared to IBS-C. }\end{array}$ & Not investigated. \\
\hline Camilleri et al. (59) & $\begin{array}{l}\text { Subgroups of IBS-D patients } \\
\text { ( } n=64) \text { were identified with } \\
\text { increased or normal levels of total } \\
\text { fecal bile acids. }\end{array}$ & $\begin{array}{l}\text { IBS-D patients with increased levels of bile acids } \\
\text { presented with more pathophysiological changes } \\
\text { such as fecal fat and changes in intestinal } \\
\text { permeability. }\end{array}$ & Not investigated. \\
\hline Dior et al. (60) & $\begin{array}{l}\text { Circulating primary bile acids were } \\
\text { elevated in both IBS-D }(n=16) \text { and } \\
\text { IBS-C }(n=15) \text { patients. } \\
\text { Fecal primary bile acids were } \\
\text { elevated in IBS-D. }\end{array}$ & $\begin{array}{l}\text { Abdominal pain was correlated with serum and } \\
\text { fecal primary bile acid concentrations. }\end{array}$ & $\begin{array}{l}\text { Escherichia coli was increased in IBS-D. } \\
\text { Bacteroides and Bifidobacterium were increased in IBS- } \\
\text { C patients. }\end{array}$ \\
\hline Zhao et al. (61) & $\begin{array}{l}24.5 \% \text { of IBS-D patients }(n=290) \\
\text { exhibited excessive excretion of } \\
\text { total fecal bile acids. }\end{array}$ & $\begin{array}{l}\text { Total fecal bile acid levels were correlated with } \\
\text { increased defecation frequency and decreased } \\
\text { stool consistency. }\end{array}$ & $\begin{array}{l}\text { Clostridia-rich microbiota was linked to excessive bile } \\
\text { acid excretion in IBS-D. }\end{array}$ \\
\hline Wei et al. (62) & $\begin{array}{l}\text { Primary bile acids were increased, } \\
\text { and secondary bile acids were } \\
\text { decreased in IBS-D patients } \\
(\mathrm{n}=55) \text {. }\end{array}$ & $\begin{array}{l}\text { Defecation frequency was associated with primary } \\
\text { bile acid concentrations. } \\
\text { Visceral pain sensitivity was negatively correlated } \\
\text { with CDCA. }\end{array}$ & $\begin{array}{l}\text { The abundance of Ruminococcaceae was decreased in } \\
\text { IBS-D patients. The changes were negatively correlated } \\
\text { with primary and positively correlated with secondary } \\
\text { bile acids. }\end{array}$ \\
\hline Wei et al. (63) & $\begin{array}{l}\text { Fecal primary bile acids were } \\
\text { increased in IBS-D (pilot study). } \\
\text { Mucosal expression of TGR5 was } \\
\text { increased in IBS-D. }\end{array}$ & $\begin{array}{l}\text { Fecal primary bile acids were correlated with } \\
\text { severity of diarrhea. } \\
\text { IBS-D patients with higher expression of TGR5 had } \\
\text { more severe and more frequent abdominal pain. }\end{array}$ & Not investigated. \\
\hline
\end{tabular}

The above table summarizes key findings relating to circulating and fecal bile acid levels in individuals with irritable bowel syndrome (IBS). Associations with IBS symptomology and, if investigated, changes in microbial profiles in the gut lumen are listed. 
In a number of clinical studies, bile acid dyshomeostasis has been detected in individuals with IBS (summarized in Table 1). It has consistently been reported that individuals with diarrheapredominant IBS have elevated concentrations of fecal primary bile acids (57-60, 62, 63). Changes in bile acid profiles were also linked with IBS-D symptoms, such as the defecation frequency $(57,58,61,62)$ and abdominal pain $(60,62,63)$. The link with IBS-C is not as strong, although fecal LCA was decreased in this subset of individuals (58). Deconjugated bile acids can drive phylum level shifts, increasing firmicutes and decreasing bacteroidetes (64). Individuals with IBS have an altered microbiome, where the ratio of fecal firmicutes to bacteroidetes is increased (65) and changes in the gut microbiome $(66,67)$ are important contributors to the pathophysiology of IBS. Several studies have examined microbial profiles and bile acid pools in IBS and found that bacteria with functions in bile acid transformation were modified in IBS-D patients (57). Others detected distinct changes in bacterial profiles. In IBS-D, E. coli (60) and clostridia-rich microbiota were elevated and associated with excessive bile acid secretion (61), whereas the abundance of ruminococcaceae was decreased (62).

\section{BIDIRECTIONAL GUT-BRAIN SIGNALING AXIS}

In health, specialized innate and adaptive immune mechanisms are important in priming the gut against possible attack from luminal pathogens. An intact epithelial barrier and primed immune response excludes both commensal and non-commensal bacteria, restricting them to the external environment of the gut lumen, although it has been reported that the presence of bacterial products in the lamina propria is actually important for maintaining homeostasis in the enteric nervous system (68). However, interoceptive signaling relating to the luminal environment of the intestines are reported to the central nervous system (CNS) (69), thus, an intrinsic cross-barrier signaling mechanism would enable signaling between luminal factors and host physiological systems.

\section{Gut-Brain Axis}

Bidirectional gut-to-brain signaling involves the peripheral nervous system, endocrine and immune mediators (70-72). Sympathetic and parasympathetic efferent nerves synapse with neurons in the neural plexi of the enteric nervous system that innervate both the submucosal and muscle layers $(73,74)$, thereby influencing intestinal secreto-motor activity. Two afferent neuronal subtypes underpin sensory function within the gut. The first, extrinsic primary afferents, have somata that are external to the gut and signal to the CNS. The second subtype, intrinsic primary afferent neurons (IPANs) have somata that are embedded within the gut wall and are primary afferents for secretory and motility reflexes. Both respond to changes in luminal content $(75,76)$ and evidence exists to support the presence of functional synapses between myenteric soma and vagal afferents, with the implication that they are the first neural link in the microbiota-gut-brain signaling axis (77).
Vagal afferents are believed to transmit information about the luminal environment through the sensitivity of its sensory endings to microbial metabolites (78). Indeed, vagal signaling has been implicated in altered central expression of neurotransmitters and changed behaviors evoked by ingestion of putative probiotics (79, 80). Behavioral changes in germ-free mice, which are born and raised under sterile conditions, implicate the critical role of microbes in the normal development of immune, endocrine and neural physiology (81). Moreover, IPANs are less excitable in germ-free mice (82), intimating microbes use neurally-mediated gut-to-brain pathways. Mechanosensory spinal afferents terminate in the serosa, muscularis and mucosa (83) and many visceral afferents are polymodal, sensing more than one stimulus modality (84). We and others have recorded changes in the excitability of vagal afferents in the jejunum $(80,85)$ and colon $(6,86,87)$ following exposure to bacterial strains or their secretory products. These afferents are appropriately positioned to sense chemo-nociceptive signals (88) such as luminal bile acids. Indeed, TGR5 has been detected on IPANs (89) and has also been implicated in gut-tobrain satiety-related signaling via the vagus nerve (90). Germ-free mice exhibit increased levels of bile acids and increased activation of TGR5 (91).

\section{Enteroendocrine Cells}

Epithelial stem cells give rise to four distinct cellular lineages, including specialized chemosensory enteroendocrine cells. Embedded amongst other enterocytes in the epithelial layer, enteroendocrine cells sense the presence of nutrients and other stimulatory factors in the luminal contents. Although they represent only $\sim 1 \%$ of the epithelial cell population, collectively these cells make up the largest hormone-secreting organ in the body. These polarized cells have an apical side which faces the gut lumen and a hormone-secreting side that releases endocrine factors basolaterally when activated (92). There are more than twenty different enteroendocrine cell types in the gut.

Serotonin (5-HT)-secreting enterochromaffin cells are one such chemosensory cell type and they are coupled to sensory nerves. Catecholamines and microbially-produced short-chain fatty acids, such as butyrate and isobutyrate (93) can stimulate 5-HT release. 5HT has a profound impact on bowel function by influencing neural modulation of intestinal smooth muscle via $5-\mathrm{HT}_{3}$ and $5-\mathrm{HT}_{4}$ receptors. Expression of SERT, proteins responsible for the reuptake of 5-HT following synaptic transmission into mucosal enterocytes and presynaptic neurons, is decreased in IBS, an aspect that may have genetic origins (94), and contributes to the pathophysiology of IBS (95). Abnormalities in postprandial serotonin release have been linked to IBS subtype, with impaired postprandial serotonin release detected in IBS-C patients, while increased plasma serotonin was identified in individuals with IBS-D $(96,97)$.

Recent research has detected expression of TGR5 in enterochromaffin cells in the colon but not the small intestine (98). In mice, 5-HT stimulated an increase in bile excretion but concomitantly increased ASBT expression, leading to lower levels of colonic bile acids (99), which is linked to decreased colonic motility, increased water reabsorption and constipation.

Glucagon-like peptide-1 (GLP-1) and peptide YY (PYY)secreting L-cells are electrically excitable biosensors integrated 
into the epithelium. They express a plethora of receptors including receptors for GABA (100), short-chain fatty acids (101) and also 5-HT (98), for which agonists can be derived from luminal bacteria. Moreover, L-cells in rodents $(102,103)$ and humans $(104,105)$ express both FXR and TGR5, making them promising candidates for sensing, translating and transmitting signals from the colonic lumen to the mammalian nervous system $(106,107)$. Indeed, in isolated human enterocytes, $73 \%$ of GLP-1 expressing enteroendocrine cells expressed TGR5, whereas only $16 \%$ of GLP-1 negative cells expressed this receptor, suggesting that L-cells are the predominant cellular transducers of TGR5-mediated bile acidmediated signals. Inhibition of ileal ABSTs using elobixibat resulted in elevated levels of circulating GLP-1, likely through increased interaction of colonic bile acids with GLP-1 secreting L-cells (108). Exposure to LCA and other bile acid TGR5 agonists resulted in increased cAMP, calcium rises and secretion of GLP1 from L-cells (109). Interestingly, TGR5 is expressed on the basolateral membrane of L-cells $(102,105,110)$, indicating that bile acids must be transported across the epithelium to stimulate GLP-1 release from L-cells. Bile acids also activate nuclear FXR in enterocytes (111). It appears that conjugated bile acids stimulate the TGR5/GLP-1 pathway, whereas CDCA activates the FXR/FGF19 pathway, decreasing expression of GLP-1 (105), emphasizing the differential receptor binding affinities for bile acids. This evidence is consistent with the existence of an epithelial-neural pathway, which could facilitate signaling from bile acids in the gut lumen to the host neurophysiological system via cellular transducers in the epithelium with precise, temporal transmission of sensory signals (106).

\section{Immune Cells}

Bile acids are noted for their antimicrobial properties which prevents small intestinal bacterial overgrowth (23). This may be mediated through direct cytotoxicity (21) or by stimulating innate immune mechanisms (22). Furthermore, diarrhea resulting from exposure to high levels of bile acids in the colon may be part of the innate immune response to protect the intestinal epithelium from cytotoxic bile acids, such as LCA (24). TGR5, FXR and VDR expression has been detected in innate immune cells such as monocytes, macrophages, dendritic cells and natural killer cells (29-31). Indeed, TGR5 activation in monocytes and macrophages evoke a reduction in the release of pro-inflammatory cytokines and phagocytic activity (112-114). Bile acids appear to have an important role in fine-tuning the immune response to the divergence of antigens that the gut is exposed to. Generally, the responses tend to be inhibitory and favor gut tolerance (115). In addition to altered microbial profiles, indicators of immune activation, such as elevated levels of proinflammatory cytokines and increased infiltration of immune cells to the lamina propria, have been described as part of the pathology of IBS $(55,116)$. Microbiota-induced changes in colonic bile acid pools could subsequently modify TGR5 or FXR function in immune cells, although the details of this potential mechanism are yet to be explored.

\section{Brain-Gut Signaling}

An adaptive or allostatic response to a perceived environmental threat underpins the stress response and is initiated by release of corticotropin-releasing factor from the hypothalamus to stimulate HPA activity. Chronic activation of the HPA axis has, however, been associated with altered bowel morphology, function and visceral pain sensitivity $(117,118)$ and is frequently co-morbid in individuals with IBS (119). Moreover, stress and activation of the HPA axis are linked to microbial dysbiosis (120), demonstrating the two-way communication between the brain and the gut. Although circulating bile acids don't normally cross the blood brain barrier, when serum bile acids are increased, as is the case in cholestasis, they can gain access to the central nervous system through a leaky blood brain barrier and become concentrated in the hypothalamus (121). An animal model of cholestasis demonstrated the transport of specific bile acids into hypothalamic neurons resulting in decreased expression and secretion of corticotropin-releasing factor with overall suppressive effects on HPA activity that is mediated through glucocorticoid receptors (122). Others have shown that supraphysiologic concentrations of bile acids in the periphery suppress hepatic glucocorticoid clearance and, in this way, inhibit activity of the HPA axis (123). Thus, bile acids may modify central regulation of gut function and thereby contribute to the pathophysiology of IBS.

\section{BILE ACIDS IN THE MANIFESTATION OF IBS SYMPTOMS}

Colonic exposure to excess bile acids, which may be due to loss of bile acid transporters in the ileum causing bile acid malabsorption (124), overproduction of bile acids, or as a secondary consequence of gastrointestinal disease, has been linked to increased intestinal secretion and motility. Bile acid malabsorption typically results in chronic watery diarrhea, a symptom also characteristic of IBS-D, although the seleniumhomocholic acid taurine test (Se-HCAT) test, which detects increased colonic bile acid exposure can differentiate between the two disorders (125). Fecal bile acids are raised in $~ 25 \%$ of individuals with IBS-D (126) resulting in accelerated colonic transit, which is linked with diarrhea and visceral pain sensitivity. Moreover, colestipol treatment, which binds bile acids and prevents reabsorption in the ileum, improved IBS symptoms (127).

\section{Altered Bowel Function: Absorpto- Secretory Function}

Modification of epithelial permeability and stimulation of prosecretory pathways involving cAMP is likely to underlie the manifestation of bile acid-evoked watery diarrhea $(128,129)$, while bile acid subtype and conjugation status will determine bile acid specific effects $(130,131)$. The capacity of specific bile acids to increase epithelial permeability may be neurally 
regulated (132), however, if tight junctions are compromised, conjugated bile salts, which, generally do not act as secretagogues $(28,133)$, can gain access to the epithelial basolateral membrane and subsequently evoke an increase in cytosolic calcium leading to chloride-mediated secretion (134). Increased excretion and synthesis of serum C4 (7 $\alpha$-hydroxy-4cholesten-3-one), which stimulates bile acid synthesis is thought to underpin this observation (135). Changes in bile acid secretion, induced by cholecystectomy increase the risk of developing functional bowel disorders such as IBS (136), with a prevalence of IBS-D (137). As bile acids accelerate colonic transit, it is unsurprising that lower concentrations of bile acids in the colon correlated with decreased gut transit time (138). Delivery of bile acids to the colon is decreased in patients with cholestasis and this has been linked to the manifestation of constipation (139), although the link between bile acids and IBS-C is less clear than in IBS-D patients (140). Nonetheless, a reduction in the concentration of fecal bile acids was detected in a subset (15\%) of individuals with IBS-C when compared with healthy volunteers. Moreover, the IBS group had notable decreases in DCA and CDCA but increased LCA. The potential for the therapeutic use of orally administered bile acids in chronic constipation (141) and IBS-C (142) or by inhibiting the active uptake of bile acids in the ileum using an ASBT inhibitor, such as elobixibat $(143,144)$ is being explored.

\section{Intestinal Motor Function}

Although the modulatory effects of bile acids on absorptosecretory function are most obvious, both primary and secondary bile acids can also modify intestinal motor function. In a patient study, modest increases in stool bile acids were noted as an underlying factor in the onset of diarrhea in individuals diagnosed with IBS-D, but who did not have bile acid malabsorption, and it was found that this was mediated by an increase in gut motility (145). Perfusion studies assessing the effects of the secondary bile acid, DCA, on feline colonic motility showed that it had significant excitatory effects on contractility (146). A similar study in humans showed that DCA caused a considerable increase in the contractile force of the colon when it was compared to the effects of the known muscarinic acetylcholine receptor agonist, carbachol. CA and CDCA had negligible effects (147). Moreover, in rabbit colonic tissue, the inhibitory actions of voltage gated sodium channel blockers implicated cholinergic and alpha adrenergic intramural neurons in the pro-kinetic actions of DCA (148). Studies in mice showed that TGR5, is highly expressed in the myenteric plexus, which regulates intestinal motility. When TGR5 was knocked-out, bile acids did not stimulate longitudinal muscle contractility, whole-gut transit was slower and fecal water content was reduced. The investigators deduced that the prokinetic effects of bile acids in the colon are mediated by TGR5 expressed on 5-HT-secreting enterochromaffin cells and calcitonin gene-related peptide-secreting intrinsic primary afferent neurons (89).

\section{Visceral Hypersensitivity}

In addition to altered bowel habit, individuals with IBS often present with bloating and abdominal pain indicative of visceral hypersensitivity. Recently reported findings from a rodent study have implicated Nerve Growth Factor (NGF) and transient receptor potential vanilloid channel (TRPV1) nociceptors in a signaling pathway where bile acids could modulate visceral pain signals. NGF, an important mediator in the generation and maintenance of pain, was upregulated following exposure to bile acids and this was mediated through activation of FXR. As mast cells synthesize, store and secrete NGF, the authors suggested that bile stimulated NGF release from mast cells, which, in turn, activated nociceptors and induced visceral hypersensitivity (149). TRPV1-expressing sensory fibers are increased in individuals with IBS (150) and visceral pain sensitivity has been linked to activation of mucosal mast cells in proximity to colonic sensory nerves in a similar cohort (151), providing a signaling axis by which bile acids could modulate visceral pain perception. In healthy volunteers, introduction of DCA (152) and CDCA (153) to the colon increased visceral pain sensitivity to rectal distension, however, thus far no correlation between fecal bile acids and abdominal pain severity and frequency in IBS-D patients, has been detected (62).

\section{DISCUSSION}

Research into the etiology of IBS recognizes the complexity of this multifactorial and heterogenous bowel disorder. There is growing evidence to support a role for bile acids in the pathophysiology of IBS, through interactions with the microbiome and host sensory and/or immune cells or through direct actions on the peripheral and central nervous system (Figure 2). The perfunctory actions of bile acids as detergents in the small intestine belie the complex functions instilled in these bioactive signaling molecules. The bidirectional relationship with gut microbiota impacts on microbial profiles and on the bile acid pool itself. The striking pro-secretory and prokinetic actions of bile acids on colonic function are consistent with the manifestation of IBS-D symptoms, whereas reduction in exposure to bile acids, though less researched, is more consistent with decreased gut secretion and transit, as presented in individuals with IBS-C. Elevated levels of excreted primary bile acids have consistently been detected in individuals with IBS-D and a growing number of studies have linked changes in fecal and serum bile acids with IBS symptomology, and changes in bacterial profiles with specific links to bacteria with bile acid transformation functionality (Table $\mathbf{1}$ ).

Mechanistically, bile acid receptors are expressed on intrinsic and extrinsic nerves, which could facilitate direct neurallymediated changes in gut function. Moreover, when bile acids are at supraphysiological levels, they can breach the blood brain barrier to modify the HPA axis, which in turn, can modulate intestinal function and luminal microbes. However, bile acid 

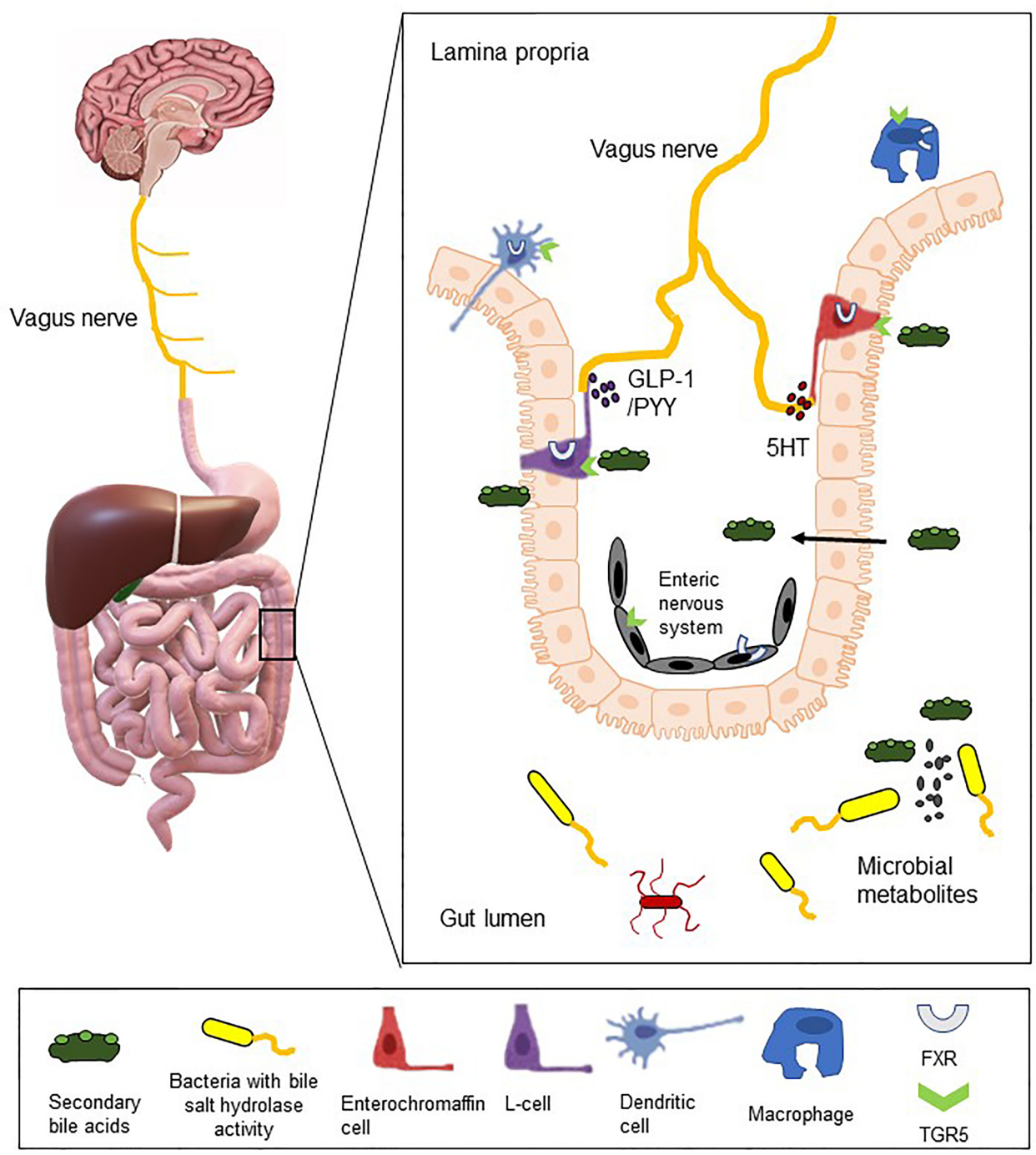

FIGURE 2 | Bile acids as bioactive molecules in the gut-brain signaling axis. The illustration depicts interactions between colonic microbes with bile salt hydrolase activity and luminal bile acids. These bile acids may subsequently bind to bile acid receptors (FXR and TGR5 illustrated), which are expressed on 5-HT-secreting enterochromaffin cells, GLP-1-secreting L-cells, immune cells and on intrinsic and extrinsic neural cells. Through direct or indirect mechanisms, bile acids may act as endocrine factors or neuromodulatory agents and thereby modify local gut function and/or gut-to-brain signaling.

receptors are also detected on enteroendocrine and immune cells, which could both act as signal transducing intermediaries, secreting factors which subsequently modify colonic activity either through direct actions or by modulating neural regulation of the gut. Further complexity lies in the variability of responses evoked by conjugated or unconjugated, primary or secondary bile acids. As bile acids have emerged as effectors in microbe-host signaling and can directly and indirectly modulate gut homeostasis, these bioactive molecules should not be overlooked as the pathophysiology of IBS is elucidated. Indeed, interventions to modify colonic exposure to bile acids could reveal effective therapeutic options for this functional bowel disorder.

\section{AUTHOR CONTRIBUTIONS}

$\mathrm{RD}, \mathrm{QX}$, and DO'M prepared this review together. All authors contributed to the article and approved the submitted version.

\section{FUNDING}

DO'M is a funded investigator in APC Microbiome Ireland, which is supported by Science Foundation Ireland [Grant SFI/ 12/RC/2273]. QX is supported by CSC, PR of China. 


\section{REFERENCES}

1. Dinan TG, Cryan JF. Gut Instincts: Microbiota as a Key Regulator of Brain Development, Ageing and Neurodegeneration. J Physiol (2017) 595(2):489503. doi: 10.1113/JP273106

2. Dinan TG, Cryan JF. Melancholic Microbes: A Link Between Gut Microbiota and Depression? Neurogastroenterol Motil (2013) 25(9):713-9. doi: $10.1111 / \mathrm{nmo} .12198$

3. Sheehan D, Shanahan F. The Gut Microbiota in Inflammatory Bowel Disease. Gastroenterol Clin North Am (2017) 46(1):143-54. doi: 10.1016/ j.gtc.2016.09.011

4. Quigley EM. Probiotics in Irritable Bowel Syndrome: The Science and the Evidence. J Clin Gastroenterol (2015) 49 Suppl 1:S60-4. doi: 10.1097/ MCG.0000000000000348

5. Yano JM, Yu K, Donaldson GP, Shastri GG, Ann P, Ma L, et al. Indigenous Bacteria From the Gut Microbiota Regulate Host Serotonin Biosynthesis. Cell (2015) 161(2):264-76. doi: 10.1016/j.cell.2015.02.047

6. Buckley MM, O'Brien R, Brosnan E, Ross RP, Stanton C, Buckley JM, et al. Glucagon-Like Peptide-1 Secreting L-Cells Coupled to Sensory Nerves Translate Microbial Signals to the Host Rat Nervous System. Front Cell Neurosci (2020) 14:95. doi: 10.3389/fncel.2020.00095

7. Lomax AE, Pradhananga S, Sessenwein JL, O’Malley D. Bacterial Modulation of Visceral Sensation: Mediators and Mechanisms. Am J Physiol Gastrointest Liver Physiol (2019) 317:G363-72. doi: 10.1152/ ajpgi.00052.2019

8. Hofmann AF, Roda A. Physicochemical Properties of Bile Acids and Their Relationship to Biological Properties: An Overview of the Problem. J Lipid Res (1984) 25:1477-89. doi: 10.1016/S0022-2275(20)34421-7

9. Guzior DV, Quinn RA. Review: Microbial Transformations of Human Bile Acids. Microbiome (2021) 9:140. doi: 10.1186/s40168-021-01101-1

10. Fiorucci S, Distrutti E. Bile Acid-Activated Receptors, Intestinal Microbiota, and the Treatment of Metabolic Disorders. Trends Mol Med (2015) 21:70214. doi: 10.1016/j.molmed.2015.09.001

11. Ward JB, Mroz MS, Keely SJ. The Bile Acid Receptor, TGR5, Regulates Basal and Cholinergic-Induced Secretory Responses in Rat Colon. Neurogastroenterol Motil (2013) 25:708-11. doi: 10.1111/nmo.12148

12. Gadaleta RM, Oldenburg B, Willemsen EC, Spit M, Murzilli S, Salvatore L, et al. Activation of Bile Salt Nuclear Receptor FXR is Repressed by ProInflammatory Cytokines Activating NF-kappaB Signaling in the Intestine. Biochim Biophys Acta (2011) 1812:851-8. doi: 10.1016/j.bbadis.2011.04.005

13. Jonas MI, Kurylowicz A, Bartoszewicz Z, Lisik W, Jonas M, Kozniewski K, et al. Vitamin D Receptor Gene Expression in Adipose Tissue of Obese Individuals is Regulated by miRNA and Correlates With the ProInflammatory Cytokine Level. Int J Mol Sci (2019) 20(21):5272. doi: 10.3390/ijms20215272

14. Deutschmann K, Reich M, Klindt C, Droge C, Spomer L, Haussinger D, et al. Bile Acid Receptors in the Biliary Tree: TGR5 in Physiology and Disease. Biochim Biophys Acta Mol Basis Dis (2018) 1864:1319-25. doi: 10.1016/ j.bbadis.2017.08.021

15. Parks DJ, Blanchard SG, Bledsoe RK, Chandra G, Consler TG, Kliewer SA, et al. Bile Acids: Natural Ligands for an Orphan Nuclear Receptor. Science (1999) 284:1365-8. doi: 10.1126/science.284.5418.1365

16. Chiang JY. Bile Acid Metabolism and Signaling. Compr Physiol (2013) 3:1191-212. doi: 10.1002/cphy.c120023

17. Mertens KL, Kalsbeek A, Soeters MR, Eggink HM. Bile Acid Signaling Pathways From the Enterohepatic Circulation to the Central Nervous System. Front Neurosci (2017) 11:617. doi: 10.3389/fnins.2017.00617

18. Jones BV, Begley M, Hill C, Gahan CG, Marchesi JR. Functional and Comparative Metagenomic Analysis of Bile Salt Hydrolase Activity in the Human Gut Microbiome. Proc Natl Acad Sci U.S.A. (2008) 105:13580-5. doi: 10.1073/pnas.0804437105

19. Philipp B. Bacterial Degradation of Bile Salts. Appl Microbiol Biotechnol (2011) 89:903-15. doi: 10.1007/s00253-010-2998-0

20. Seedorf H, Griffin NW, Ridaura VK, Reyes A, Cheng J, Rey FE, et al. Bacteria From Diverse Habitats Colonize and Compete in the Mouse Gut. Cell (2014) 159:253-66. doi: 10.1016/j.cell.2014.09.008

21. Begley M, Gahan CG, Hill C. The Interaction Between Bacteria and Bile. FEMS Microbiol Rev (2005) 29:625-51. doi: 10.1016/j.femsre.2004.09.003
22. D’Aldebert E, Biyeyeme Bi Mve MJ, Mergey M, Wendum D, Firrincieli D, Coilly A, et al. Bile Salts Control the Antimicrobial Peptide Cathelicidin Through Nuclear Receptors in the Human Biliary Epithelium. Gastroenterology (2009) 136:1435-43. doi: 10.1053/j.gastro.2008.12.040

23. Dawson PA, Karpen SJ. Intestinal Transport and Metabolism of Bile Acids. J Lipid Res (2015) 56:1085-99. doi: 10.1194/jlr.R054114

24. Hegyi P, Maleth J, Walters JR, Hofmann AF, Keely SJ. Guts and Gall: Bile Acids in Regulation of Intestinal Epithelial Function in Health and Disease. Physiol Rev (2018) 98:1983-2023. doi: 10.1152/physrev.00054.2017

25. Foley MH, O’Flaherty S, Barrangou R, Theriot CM. Bile Salt Hydrolases: Gatekeepers of Bile Acid Metabolism and Host-Microbiome Crosstalk in the Gastrointestinal Tract. PloS Pathog (2019) 15:e1007581. doi: 10.1371/ journal.ppat.1007581

26. Ridlon JM, Harris SC, Bhowmik S, Kang DJ, Hylemon PB. Consequences of Bile Salt Biotransformations by Intestinal Bacteria. Gut Microbes (2016) 7:22-39. doi: 10.1080/19490976.2015.1127483

27. Zhou Y, Maxwell KN, Sezgin E, Lu M, Liang H, Hancock JF, et al. Bile Acids Modulate Signaling by Functional Perturbation of Plasma Membrane Domains. J Biol Chem (2013) 288:35660-70. doi: 10.1074/jbc.M113.519116

28. Bajor A, Gillberg PG, Abrahamsson H. Bile Acids: Short and Long Term Effects in the Intestine. Scand J Gastroenterol (2010) 45:645-64. doi: 10.3109/ 00365521003702734

29. Cipriani S, Mencarelli A, Chini MG, Distrutti E, Renga B, Bifulco G, et al. The Bile Acid Receptor GPBAR-1 (TGR5) Modulates Integrity of Intestinal Barrier and Immune Response to Experimental Colitis. PloS One (2011) 6: e25637. doi: 10.1371/journal.pone.0025637

30. Maruyama T, Miyamoto Y, Nakamura T, Tamai Y, Okada H, Sugiyama E, et al. Identification of Membrane-Type Receptor for Bile Acids (M-BAR). Biochem Biophys Res Commun (2002) 298:714-9. doi: 10.1016/S0006-291X(02)02550-0

31. Vavassori P, Mencarelli A, Renga B, Distrutti E, Fiorucci S. The Bile Acid Receptor FXR is a Modulator of Intestinal Innate Immunity. I Immunol (2009) 183:6251-61. doi: 10.4049/jimmunol.0803978

32. Makishima M, Okamoto A, Repa J, Tu H, Learned R, Luk A, et al. Identification of a Nuclear Receptor for Bile Acids. Sci (New York NY) (1999) 284:1362-5. doi: 10.1126/science.284.5418.1362

33. Wang H, Chen J, Hollister K, Sowers L, Forman B. Endogenous Bile Acids are Ligands for the Nuclear Receptor FXR/BAR. Mol Cell (1999) 3:543-53. doi: 10.1016/S1097-2765(00)80348-2

34. Laffitte B, Kast H, Nguyen C, Zavacki A, Moore D, Edwards P. Identification of the DNA Binding Specificity and Potential Target Genes for the Farnesoid X-Activated Receptor. J Biol Chem (2000) 275:10638-47. doi: 10.1074/ jbc.275.14.10638

35. Degirolamo C, Modica S, Vacca M, Di Tullio G, Morgano A, D’Orazio A, et al. Prevention of Spontaneous Hepatocarcinogenesis in Farnesoid X Receptor-Null Mice by Intestinal-Specific Farnesoid X Receptor Reactivation. Hepatol (Baltimore Md) (2015) 61:161-70. doi: 10.1002/hep.27274

36. Dempsey JL, Wang D, Siginir G, Fei Q, Raftery D, Gu H, et al. Pharmacological Activation of PXR and CAR Downregulates Distinct Bile Acid-Metabolizing Intestinal Bacteria and Alters Bile Acid Homeostasis. Toxicol Sci (2019) 168:40-60. doi: 10.1093/toxsci/kfy271

37. Makishima M, Lu T, Xie W, Whitfield G, Domoto H, Evans R, et al. Vitamin D Receptor as an Intestinal Bile Acid Sensor. Sci (New York NY) (2002) 296:1313-6. doi: 10.1126/science.1070477

38. McCarthy T, Li X, Sinal C. Vitamin D Receptor-Dependent Regulation of Colon Multidrug Resistance-Associated Protein 3 Gene Expression by Bile Acids. J Biol Chem (2005) 280:23232-42. doi: 10.1074/jbc.M411520200

39. Cheng J, Fang Z, Kim J, Krausz K, Tanaka N, Chiang J, et al. Intestinal CYP3A4 Protects Against Lithocholic Acid-Induced Hepatotoxicity in Intestine-Specific VDR-Deficient Mice. J Lipid Res (2014) 55:455-65. doi: 10.1194/jlr.M044420

40. Kawamata Y, Fujii R, Hosoya M, Harada M, Yoshida H, Miwa M, et al. A G Protein-Coupled Receptor Responsive to Bile Acids. J Biol Chem (2003) 278:9435-40. doi: 10.1074/jbc.M209706200

41. Guo C, Chen WD, Wang YD. TGR5, Not Only a Metabolic Regulator. Front Physiol (2016) 7:646. doi: 10.3389/fphys.2016.00646

42. Kwong E, Li Y, Hylemon PB, Zhou H. Bile Acids and Sphingosine-1Phosphate Receptor 2 in Hepatic Lipid Metabolism. Acta Pharm Sin B (2015) 5:151-7. doi: 10.1016/j.apsb.2014.12.009 
43. Gohlke H, Schmitz B, Sommerfeld A, Reinehr R, Haussinger D. Alpha5 Beta1-Integrins are Sensors for Tauroursodeoxycholic Acid in Hepatocytes. Hepatology (2013) 57:1117-29. doi: 10.1002/hep.25992

44. Dawson PA. Role of the Intestinal Bile Acid Transporters in Bile Acid and Drug Disposition. Handb Exp Pharmacol (2011), 169-203. doi: 10.1007/9783-642-14541-4_4

45. Lovell RM, Ford AC. Global Prevalence of and Risk Factors for Irritable Bowel Syndrome: A Meta-Analysis. Clin Gastroenterol Hepatol (2012) 10:712-721 e4. doi: 10.1016/j.cgh.2012.02.029

46. Enck P, Aziz Q, Barbara G, Farmer AD, Fukudo S, Mayer EA, et al. Irritable Bowel Syndrome. Nat Rev Dis Primers (2016) 2:16014. doi: 10.1038/ nrdp. 2016.14

47. Dinan TG, Cryan J, Shanahan F, Keeling PW, Quigley EM. IBS: An Epigenetic Perspective. Nat Rev Gastroenterol Hepatol (2010) 7:465-71. doi: 10.1038/nrgastro.2010.99

48. Barbara G, Cremon C, Carini G, Bellacosa L, Zecchi L, De Giorgio R, et al. The Immune System in Irritable Bowel Syndrome. J Neurogastroenterol Motil (2011) 17:349-59. doi: 10.5056/jnm.2011.17.4.349

49. Kim YS, Kim N. Sex-Gender Differences in Irritable Bowel Syndrome. J Neurogastroenterol Motil (2018) 24:544-58. doi: 10.5056/jnm18082

50. De Giorgio R, Volta U, Gibson PR. Sensitivity to Wheat, Gluten and FODMAPs in IBS: Facts or Fiction? Gut (2016) 65:169-78. doi: 10.1136/ gutjnl-2015-309757

51. McIntosh K, Reed DE, Schneider T, Dang F, Keshteli AH, De Palma G, et al. FODMAPs Alter Symptoms and the Metabolome of Patients With IBS: A Randomised Controlled Trial. Gut (2017) 66(7):1241-51. doi: 10.1136/ gutjnl-2015-311339

52. Dinan TG, Quigley EM, Ahmed SM, Scully P, O’Brien S, O'Mahony L, et al. Hypothalamic-Pituitary-Gut Axis Dysregulation in Irritable Bowel Syndrome: Plasma Cytokines as a Potential Biomarker? Gastroenterology (2006) 130:304-11. doi: 10.1053/j.gastro.2005.11.033

53. Drossman DA, Creed FH, Olden KW, Svedlund J, Toner BB, Whitehead WE. Psychosocial Aspects of the Functional Gastrointestinal Disorders. Gut (1999) 45 Suppl 2:II25-30. doi: 10.1136/gut.45.2008.ii25

54. Buckley MM, O’Mahony SM, O'Malley D. Convergence of NeuroEndocrine-Immune Pathways in the Pathophysiology of Irritable Bowel Syndrome. World J Gastroenterol (2014) 20:8846-58. doi: 10.3748/ wjg.v20.i27.8846

55. O'Malley D. Neuroimmune Cross Talk in the Gut. Neuroendocrine and Neuroimmune Pathways Contribute to the Pathophysiology of Irritable Bowel Syndrome. Am J Physiol Gastrointest Liver Physiol (2016) 311:G93441. doi: 10.1152/ajpgi.00272.2016

56. Kennedy PJ, Cryan JF, Quigley EM, Dinan TG, Clarke G. A Sustained Hypothalamic-Pituitary-Adrenal Axis Response to Acute Psychosocial Stress in Irritable Bowel Syndrome. Psychol Med (2014) 44:3123-34. doi: 10.1017/S003329171400052X

57. Duboc H, Rainteau D, Rajca S, Humbert L, Farabos D, Maubert M, et al. Increase in Fecal Primary Bile Acids and Dysbiosis in Patients With Diarrhea-Predominant Irritable Bowel Syndrome. Neurogastroenterol Motil (2012) 24:513-20, e246-7. doi: 10.1111/j.1365-2982.2012.01893.x

58. Shin A, Camilleri M, Vijayvargiya P, Busciglio I, Burton D, Ryks M, et al. Bowel Functions, Fecal Unconjugated Primary and Secondary Bile Acids, and Colonic Transit in Patients With Irritable Bowel Syndrome. Clin Gastroenterol Hepatol (2013) 11:1270-1275 e1. doi: 10.1016/j.cgh.2013. 04.020

59. Camilleri M, Busciglio I, Acosta A, Shin A, Carlson P, Burton D, et al. Effect of Increased Bile Acid Synthesis or Fecal Excretion in Irritable Bowel Syndrome-Diarrhea. Am J Gastroenterol (2014) 109:1621-30. doi: 10.1038/ ajg. 2014.215

60. Dior M, Delagreverie H, Duboc H, Jouet P, Coffin B, Brot L, et al. Interplay Between Bile Acid Metabolism and Microbiota in Irritable Bowel Syndrome. Neurogastroenterol Motil (2016) 28:1330-40. doi: 10.1111/nmo.12829

61. Zhao L, Yang W, Chen Y, Huang F, Lu L, Lin C, et al. A Clostridia-Rich Microbiota Enhances Bile Acid Excretion in Diarrhea-Predominant Irritable Bowel Syndrome. J Clin Invest (2020) 130:438-50. doi: 10.1172/JCI130976

62. Wei W, Wang HF, Zhang Y, Zhang YL, Niu BY, Yao SK. Altered Metabolism of Bile Acids Correlates With Clinical Parameters and the Gut Microbiota in Patients With Diarrhea-Predominant Irritable Bowel
Syndrome. World J Gastroenterol (2020) 26:7153-72. doi: 10.3748/wjg.v26. i45.7153

63. Wei W, Wang H, Zhang Y, Zhang Y, Niu B, Chen S, et al. Faecal Bile Acids and Colonic Bile Acid Membrane Receptor Correlate With Symptom Severity of Diarrhoea-Predominant Irritable Bowel Syndrome: A Pilot Study. Dig Liver Dis (2021) 53:1120-7. doi: 10.1016/j.dld.2021.04.022

64. Islam KB, Fukiya S, Hagio M, Fujii N, Ishizuka S, Ooka T, et al. Bile Acid is a Host Factor That Regulates the Composition of the Cecal Microbiota in Rats. Gastroenterology (2011) 141:1773-81. doi: 10.1053/j.gastro.2011.07.046

65. Rajilic-Stojanovic M, Biagi E, Heilig HG, Kajander K, Kekkonen RA, Tims S, et al. Global and Deep Molecular Analysis of Microbiota Signatures in Fecal Samples From Patients With Irritable Bowel Syndrome. Gastroenterology (2011) 141:1792-801. doi: 10.1053/j.gastro.2011.07.043

66. Quigley EMM. The Gut-Brain Axis and the Microbiome: Clues to Pathophysiology and Opportunities for Novel Management Strategies in Irritable Bowel Syndrome (IBS). J Clin Med (2018) 7(1):6. doi: 10.3390/ jcm7010006

67. Kennedy PJ, Cryan JF, Dinan TG, Clarke G. Irritable Bowel Syndrome: A Microbiome-Gut-Brain Axis Disorder? World J Gastroenterol (2014) 20:14105-25. doi: 10.3748/wjg.v20.i39.14105

68. Anitha M, Vijay-Kumar M, Sitaraman SV, Gewirtz AT, Srinivasan S. Gut Microbial Products Regulate Murine Gastrointestinal Motility via Toll-Like Receptor 4 Signaling. Gastroenterology (2012) 143:1006-16 e4. doi: 10.1053/ j.gastro.2012.06.034

69. Mayer EA. Gut Feelings: The Emerging Biology of Gut-Brain Communication. Nat Rev Neurosci (2011) 12:453-66. doi: 10.1038/nrn3071

70. Rhee SH, Pothoulakis C, Mayer EA. Principles and Clinical Implications of the Brain-Gut-Enteric Microbiota Axis. Nat Rev Gastroenterol Hepatol (2009) 6:306-14. doi: 10.1038/nrgastro.2009.35

71. Gareau MG, Silva MA, Perdue MH. Pathophysiological Mechanisms of Stress-Induced Intestinal Damage. Curr Mol Med (2008) 8:274-81. doi: 10.2174/156652408784533760

72. Öhman L, Törnblom H, Simrén M. Crosstalk at the Mucosal Border: Importance of the Gut Microenvironment in IBS. Nat Rev Gastroenterol Hepatol (2015) 12:36-49. doi: 10.1038/nrgastro.2014.200

73. Koeppen B, Stanton B. Berne and Levy Physiology. Philadelphia, PA :Mosby/ Elsevier (2009).

74. Boron WE, Boulpaep EL. Medical Physiology. Philadelphia, PA: Elsevier (2016).

75. Bravo JA, Forsythe P, Chew MV, Escaravage E, Savignac HM, Dinan TG, et al. Ingestion of Lactobacillus Strain Regulates Emotional Behavior and Central GABA Receptor Expression in a Mouse via the Vagus Nerve. Proc Natl Acad Sci U.S.A. (2011) 108:16050-5. doi: 10.1073/pnas.1102999108

76. Forsythe P, Kunze WA. Voices From Within: Gut Microbes and the CNS. Cell Mol Life Sci (2013) 70:55-69. doi: 10.1007/s00018-012-1028-z

77. Perez-Burgos A, Mao YK, Bienenstock J, Kunze WA. The Gut-Brain Axis Rewired: Adding a Functional Vagal Nicotinic "Sensory Synapse". FASEB J (2014) 28:3064-74. doi: 10.1096/fj.13-245282

78. Bonaz B, Bazin T, Pellissier S. The Vagus Nerve at the Interface of the Microbiota-Gut-Brain Axis. Front Neurosci (2018) 12:49. doi: 10.3389/ fnins.2018.00049

79. Bercik P, Park AJ, Sinclair D, Khoshdel A, Lu J, Huang X, et al. The Anxiolytic Effect of Bifidobacterium Longum NCC3001 Involves Vagal Pathways for Gut-Brain Communication. Neurogastroenterol Motil (2011) 23:1132-9. doi: 10.1111/j.1365-2982.2011.01796.x

80. Perez-Burgos A, Wang B, Mao YK, Mistry B, McVey Neufeld KA, Bienenstock J, et al. Psychoactive Bacteria Lactobacillus Rhamnosus (JB-1) Elicits Rapid Frequency Facilitation in Vagal Afferents. Am J Physiol Gastrointest Liver Physiol (2013) 304:G211-20. doi: 10.1152/ajpgi.00128.2012

81. Clarke G, Stilling RM, Kennedy PJ, Stanton C, Cryan JF, Dinan TG. Minireview: Gut Microbiota: The Neglected Endocrine Organ. Mol Endocrinol (2014) 28:1221-38. doi: 10.1210/me.2014-1108

82. McVey Neufeld KA, Perez-Burgos A, Mao YK, Bienenstock J, Kunze WA. The Gut Microbiome Restores Intrinsic and Extrinsic Nerve Function in Germ-Free Mice Accompanied by Changes in Calbindin. Neurogastroenterol Motil (2015) 27:627-36. doi: 10.1111/nmo.12534

83. Brierley SM, Jones RC3rd, Gebhart GF, Blackshaw LA. Splanchnic and Pelvic Mechanosensory Afferents Signal Different Qualities of Colonic 
Stimuli in Mice. Gastroenterology (2004) 127:166-78. doi: 10.1053/ j.gastro.2004.04.008

84. Su X, Gebhart GF. Mechanosensitive Pelvic Nerve Afferent Fibers Innervating the Colon of the Rat are Polymodal in Character. J Neurophysiol (1998) 80:2632-44. doi: 10.1152/jn.1998.80.5.2632

85. Perez-Burgos A, Wang L, McVey Neufeld KA, Mao YK, Ahmadzai M, Janssen LJ, et al. The TRPV1 Channel in Rodents is a Major Target for Antinociceptive Effect of the Probiotic Lactobacillus Reuteri DSM 17938. J Physiol (2015) 593:3943-57. doi: 10.1113/JP270229

86. Buckley MM, O'Brien R, Buckley JM, O’Malley D. GHSR-1 Agonist Sensitizes Rat Colonic Intrinsic and Extrinsic Neurons to Exendin-4: A Role in the Manifestation of Postprandial Gastrointestinal Symptoms in Irritable Bowel Syndrome? Neurogastroenterol Motil (2019) 31(10):e13684. doi: $10.1111 /$ nmo. 13684

87. Buckley MM, O'Malley D. Development of an Ex Vivo Method for MultiUnit Recording of Microbiota-Colonic-Neural Signaling in Real Time. Front Neurosci (2018) 12:112. doi: 10.3389/fnins.2018.00112

88. Lamb K, Kang YM, Gebhart GF, Bielefeldt K. Gastric Inflammation Triggers Hypersensitivity to Acid in Awake Rats. Gastroenterology (2003) 125:14108. doi: 10.1016/j.gastro.2003.07.010

89. Alemi F, Poole DP, Chiu J, Schoonjans K, Cattaruzza F, Grider JR, et al. The Receptor TGR5 Mediates the Prokinetic Actions of Intestinal Bile Acids and is Required for Normal Defecation in Mice. Gastroenterology (2013) 144:145-54. doi: 10.1053/j.gastro.2012.09.055

90. Wu X, Li JY, Lee A, Lu YX, Zhou SY, Owyang C. Satiety Induced by Bile Acids is Mediated via Vagal Afferent Pathways. JCI Insight (2020) 5(14): e132400. doi: 10.1172/jci.insight. 132400

91. Selwyn FP, Csanaky IL, Zhang Y, Klaassen CD. Importance of Large Intestine in Regulating Bile Acids and Glucagon-Like Peptide-1 in GermFree Mice. Drug Metab Dispos (2015) 43:1544-56. doi: 10.1124/dmd.115. 065276

92. Raybould HE. Gut Chemosensing: Interactions Between Gut Endocrine Cells and Visceral Afferents. Auton Neurosci (2010) 153:41-6. doi: 10.1016/ j.autneu.2009.07.007

93. Bellono NW, Bayrer JR, Leitch DB, Castro J, Zhang C, O'Donnell TA, et al. Enterochromaffin Cells Are Gut Chemosensors That Couple to Sensory Neural Pathways. Cell (2017) 170:185-198 e16. doi: 10.1016/j.cell.2017.05.034

94. Jin DC, Cao HL, Xu MQ, Wang SN, Wang YM, Yan F, et al. Regulation of the Serotonin Transporter in the Pathogenesis of Irritable Bowel Syndrome. World J Gastroenterol (2016) 22:8137-48. doi: 10.3748/wjg.v22.i36.8137

95. Camilleri M. Serotonin in the Gastrointestinal Tract. Curr Opin Endocrinol Diabetes Obes (2009) 16:53-9. doi: 10.1097/MED.0b013e32831e9c8e

96. Dunlop SP, Coleman NS, Blackshaw E, Perkins AC, Singh G, Marsden CA, et al. Abnormalities of 5-Hydroxytryptamine Metabolism in Irritable Bowel Syndrome. Clin Gastroenterol Hepatol (2005) 3:349-57. doi: 10.1016/S15423565(04)00726-8

97. Houghton LA, Atkinson W, Whitaker RP, Whorwell PJ, Rimmer MJ. Increased Platelet Depleted Plasma 5-Hydroxytryptamine Concentration Following Meal Ingestion in Symptomatic Female Subjects With Diarrhoea Predominant Irritable Bowel Syndrome. Gut (2003) 52:663-70. doi: 10.1136/ gut.52.5.663

98. Lund ML, Egerod KL, Engelstoft MS, Dmytriyeva O, Theodorsson E, Patel BA, et al. Enterochromaffin 5-HT Cells - A Major Target for GLP-1 and Gut Microbial Metabolites. Mol Metab (2018) 11:70-83. doi: 10.1016/ j.molmet.2018.03.004

99. Watanabe H, Akasaka D, Ogasawara H, Sato K, Miyake M, Saito K, et al. Peripheral Serotonin Enhances Lipid Metabolism by Accelerating Bile Acid Turnover. Endocrinology (2010) 151:4776-86. doi: 10.1210/en.2009-1349

100. Gameiro A, Reimann F, Habib AM, O'Malley D, Williams L, Simpson AK, et al. The Neurotransmitters Glycine and GABA Stimulate Glucagon-Like Peptide-1 Release From the GLUTag Cell Line. J Physiol (2005) 569:761-72. doi: 10.1113/jphysiol.2005.098962

101. Tolhurst G, Heffron H, Lam YS, Parker HE, Habib AM, Diakogiannaki E, et al. Short-Chain Fatty Acids Stimulate Glucagon-Like Peptide-1 Secretion via the G-Protein-Coupled Receptor FFAR2. Diabetes (2012) 61:364-71. doi: $10.2337 / \mathrm{db} 11-1019$

102. Christiansen CB, Trammell SAJ, Wewer Albrechtsen NJ, Schoonjans K, Albrechtsen R, Gillum MP, et al. Bile Acids Drive Colonic Secretion of
Glucagon-Like-Peptide 1 and Peptide-YY in Rodents. Am J Physiol Gastrointest Liver Physiol (2019) 316:G574-84. doi: 10.1152/ajpgi. 00010.2019

103. Katsuma S, Hirasawa A, Tsujimoto G. Bile Acids Promote Glucagon-Like Peptide-1 Secretion Through TGR5 in a Murine Enteroendocrine Cell Line STC-1. Biochem Biophys Res Commun (2005) 329:386-90. doi: 10.1016/ j.bbrc.2005.01.139

104. Trabelsi MS, Daoudi M, Prawitt J, Ducastel S, Touche V, Sayin SI, et al. Farnesoid X Receptor Inhibits Glucagon-Like Peptide-1 Production by Enteroendocrine L Cells. Nat Commun (2015) 6:7629. doi: 10.1038/ ncomms 8629

105. Calderon G, McRae A, Rievaj J, Davis J, Zandvakili I, Linker-Nord S, et al. Ileo-Colonic Delivery of Conjugated Bile Acids Improves Glucose Homeostasis via Colonic GLP-1-Producing Enteroendocrine Cells in Human Obesity and Diabetes. EBioMedicine (2020) 55:102759. doi: 10.1016/j.ebiom.2020.102759

106. Bohorquez DV, Shahid RA, Erdmann A, Kreger AM, Wang Y, Calakos N, et al. Neuroepithelial Circuit Formed by Innervation of Sensory Enteroendocrine Cells. J Clin Invest (2015) 125:782-6. doi: 10.1172/JCI78361

107. Chimerel C, Emery E, Summers DK, Keyser U, Gribble FM, Reimann F. Bacterial Metabolite Indole Modulates Incretin Secretion From Intestinal Enteroendocrine L Cells. Cell Rep (2014) 9:1202-8. doi: 10.1016/ j.celrep.2014.10.032

108. Rudling M, Camilleri M, Graffner H, Holst JJ, Rikner L. Specific Inhibition of Bile Acid Transport Alters Plasma Lipids and GLP-1. BMC Cardiovasc Disord (2015) 15:75. doi: 10.1186/s12872-015-0070-9

109. Parker HE, Wallis K, le Roux CW, Wong KY, Reimann F, Gribble FM. Molecular Mechanisms Underlying Bile Acid-Stimulated Glucagon-Like Peptide-1 Secretion. Br J Pharmacol (2012) 165:414-23. doi: 10.1111/ j.1476-5381.2011.01561.x

110. Brighton CA, Rievaj J, Kuhre RE, Glass LL, Schoonjans K, Holst JJ, et al. Bile Acids Trigger GLP-1 Release Predominantly by Accessing Basolaterally Located G Protein-Coupled Bile Acid Receptors. Endocrinology (2015) 156:3961-70. doi: 10.1210/en.2015-1321

111. Burrin D, Stoll B, Moore D. Digestive Physiology of the Pig Symposium: Intestinal Bile Acid Sensing is Linked to Key Endocrine and Metabolic Signaling Pathways. J Anim Sci (2013) 91:1991-2000. doi: 10.2527/jas.2013-6331

112. Haselow K, Bode JG, Wammers M, Ehlting C, Keitel V, Kleinebrecht L, et al. Bile Acids PKA-Dependently Induce a Switch of the IL-10/IL-12 Ratio and Reduce Proinflammatory Capability of Human Macrophages. J Leukoc Biol (2013) 94:1253-64. doi: 10.1189/jlb.0812396

113. Perino A, Pols TW, Nomura M, Stein S, Pellicciari R, Schoonjans K. TGR5 Reduces Macrophage Migration Through mTOR-Induced C/EBPbeta Differential Translation. J Clin Invest (2014) 124:5424-36. doi: 10.1172/JCI76289

114. Pols TW, Noriega LG, Nomura M, Auwerx J, Schoonjans K. The Bile Acid Membrane Receptor TGR5 as an Emerging Target in Metabolism and Inflammation. J Hepatol (2011) 54:1263-72. doi: 10.1016/j.jhep.2010.12.004

115. Fiorucci S, Biagioli M, Zampella A, Distrutti E. Bile Acids Activated Receptors Regulate Innate Immunity. Front Immunol (2018) 9:1853. doi: 10.3389/fimmu.2018.01853

116. O’Malley D, Quigley EM, Dinan TG, Cryan JF. Do Interactions Between Stress and Immune Responses Lead to Symptom Exacerbations in Irritable Bowel Syndrome? Brain Behav Immun (2011) 25:1333-41. doi: 10.1016/ j.bbi.2011.04.009

117. Bhatia V, Tandon RK. Stress and the Gastrointestinal Tract. J Gastroenterol Hepatol (2005) 20:332-9. doi: 10.1111/j.1440-1746.2004.03508.x

118. O’Malley D, Julio-Pieper M, Gibney SM, Dinan TG, Cryan JF. Distinct Alterations in Colonic Morphology and Physiology in Two Rat Models of Enhanced Stress-Induced Anxiety and Depression-Like Behaviour. Stress (2010) 13:114-22. doi: 10.3109/10253890903067418

119. Spiller RC. Irritable Bowel Syndrome. Br Med Bull (2004) 72:15-29. doi: 10.1093/bmb/ldh039

120. Madison A, Kiecolt-Glaser JK. Stress, Depression, Diet, and the Gut Microbiota: Human-Bacteria Interactions at the Core of Psychoneuroimmunology and Nutrition. Curr Opin Behav Sci (2019) 28:105-10. doi: 10.1016/j.cobeha. 2019.01.011

121. Quinn M, McMillin M, Galindo C, Frampton G, Pae HY, DeMorrow S. Bile Acids Permeabilize the Blood Brain Barrier After Bile Duct Ligation in Rats 
via Rac1-Dependent Mechanisms. Dig Liver Dis (2014) 46:527-34. doi: 10.1016/j.dld.2014.01.159

122. McMillin M, Frampton G, Quinn M, Divan A, Grant S, Patel N, et al. Suppression of the HPA Axis During Cholestasis Can Be Attributed to Hypothalamic Bile Acid Signaling. Mol Endocrinol (2015) 29:1720-30. doi: 10.1210/me.2015-1087

123. McNeilly AD, Macfarlane DP, O’Flaherty E, Livingstone DE, Mitic T, McConnell KM, et al. Bile Acids Modulate Glucocorticoid Metabolism and the Hypothalamic-Pituitary-Adrenal Axis in Obstructive Jaundice. J Hepatol (2010) 52:705-11. doi: 10.1016/j.jhep.2009.10.037

124. Camilleri M. Advances in Understanding of Bile Acid Diarrhea. Expert Rev Gastroenterol Hepatol (2014) 8:49-61. doi: 10.1586/17474124.2014.851599

125. Boyd GS, Merrick MV, Monks R, Thomas IL. Se-75-Labeled Bile Acid Analogs, New Radiopharmaceuticals for Investigating the Enterohepatic Circulation. J Nucl Med (1981) 22:720-5.

126. Slattery SA, Niaz O, Aziz Q, Ford AC, Farmer AD. Systematic Review With Meta-Analysis: The Prevalence of Bile Acid Malabsorption in the Irritable Bowel Syndrome With Diarrhoea. Aliment Pharmacol Ther (2015) 42:3-11. doi: 10.1111/apt.13227

127. Bajor A, Tornblom H, Rudling M, Ung KA, Simren M. Increased Colonic Bile Acid Exposure: A Relevant Factor for Symptoms and Treatment in IBS. Gut (2015) 64:84-92. doi: 10.1136/gutjnl-2013-305965

128. Conley DR, Coyne MJ, Bonorris GG, Chung A, Schoenfield LJ. Bile Acid Stimulation of Colonic Adenylate Cyclase and Secretion in the Rabbit. Am J Dig Dis (1976) 21:453-8. doi: 10.1007/BF01072128

129. Coyne MJ, Bonorris GG, Chung A, Conley DR, Croke J, Schoenfield LJ. Inhibition by Propranolol of Bile Acid Stimulation of Rabbit Colonic Adenylate Cyclase In Vitro. Gastroenterology (1976) 71:68-71. doi: 10.1016/S0016-5085(76)80099-6

130. Chadwick VS, Gaginella TS, Carlson GL, Debongnie JC, Phillips SF, Hofmann AF. Effect of Molecular Structure on Bile Acid-Induced Alterations in Absorptive Function, Permeability, and Morphology in the Perfused Rabbit Colon. J Lab Clin Med (1979) 94:661-74.

131. Mekjian HS, Phillips SF, Hofmann AF. Colonic Secretion of Water and Electrolytes Induced by Bile Acids: Perfusion Studies in Man. J Clin Invest (1971) 50:1569-77. doi: 10.1172/JCI106644

132. Sun Y, Fihn BM, Sjovall H, Jodal M. Enteric Neurones Modulate the Colonic Permeability Response to Luminal Bile Acids in Rat Colon In Vivo. Gut (2004) 53:362-7. doi: 10.1136/gut.2003.015867

133. Keely SJ, Scharl MM, Bertelsen LS, Hagey LR, Barrett KE, Hofmann AF. Bile Acid-Induced Secretion in Polarized Monolayers of T84 Colonic Epithelial Cells: Structure-Activity Relationships. Am J Physiol Gastrointest Liver Physiol (2007) 292:G290-7. doi: 10.1152/ajpgi.00076.2006

134. Dharmsathaphorn K, Huott PA, Vongkovit P, Beuerlein G, Pandol SJ, Ammon HV. Cl- Secretion Induced by Bile Salts. A Study of the Mechanism of Action Based on a Cultured Colonic Epithelial Cell Line. J Clin Invest (1989) 84:945-53. doi: 10.1172/JCI114257

135. Valentin N, Camilleri M, Altayar O, Vijayvargiya P, Acosta A, Nelson AD, et al. Biomarkers for Bile Acid Diarrhoea in Functional Bowel Disorder With Diarrhoea: A Systematic Review and Meta-Analysis. Gut (2016) 65:1951-9. doi: 10.1136/gutjnl-2015-309889

136. Kennedy TM, Jones RH. Epidemiology of Cholecystectomy and Irritable Bowel Syndrome in a UK Population. Br J Surg (2000) 87:1658-63. doi: 10.1046/j.1365-2168.2000.01596.x

137. Sciarretta G, Furno A, Mazzoni M, Malaguti P. Post-Cholecystectomy Diarrhea: Evidence of Bile Acid Malabsorption Assessed by SeHCAT Test. Am J Gastroenterol (1992) 87:1852-4.

138. Vijayvargiya P, Busciglio I, Burton D, Donato L, Lueke A, Camilleri M. Bile Acid Deficiency in a Subgroup of Patients With Irritable Bowel Syndrome With Constipation Based on Biomarkers in Serum and Fecal Samples. Clin Gastroenterol Hepatol (2018) 16:522-7. doi: 10.1016/j.cgh.2017.06.039

139. Ghaffari K, Savadkuhi ST, Honar H, Riazi K, Shafaroodi H, Moezi L, et al. Obstructive Cholestasis Alters Intestinal Transit in Mice: Role of Opioid System. Life Sci (2004) 76:397-406. doi: 10.1016/j.lfs.2004.09.002

140. Wald A. Bile Acids and Bowel Function: Do They Play a Role in Constipation-Associated Irritable Bowel Syndrome? Clin Gastroenterol Hepatol (2018) 16:486-7. doi: 10.1016/j.cgh.2017.11.021
141. Bazzoli F, Malavolti M, Petronelli A, Barbara L, Roda E. Treatment of Constipation With Chenodeoxycholic Acid. J Int Med Res (1983) 11:120-3. doi: $10.1177 / 030006058301100211$

142. Rao AS, Wong BS, Camilleri M, Odunsi-Shiyanbade ST, McKinzie S, Ryks $\mathrm{M}$, et al. Chenodeoxycholate in Females With Irritable Bowel SyndromeConstipation: A Pharmacodynamic and Pharmacogenetic Analysis. Gastroenterology (2010) 139:1549-58, 1558 e1. doi: 10.1053/j.gastro. 2010.07.052

143. Acosta A, Camilleri M. Elobixibat and its Potential Role in Chronic Idiopathic Constipation. Therap Adv Gastroenterol (2014) 7:167-75. doi: $10.1177 / 1756283 X 14528269$

144. Thomas RH, Luthin DR. Current and Emerging Treatments for Irritable Bowel Syndrome With Constipation and Chronic Idiopathic Constipation: Focus on Prosecretory Agents. Pharmacotherapy (2015) 35:613-30. doi: $10.1002 /$ phar.1594

145. Peleman C, Camilleri M, Busciglio I, Burton D, Donato L, Zinsmeister AR. Colonic Transit and Bile Acid Synthesis or Excretion in Patients With Irritable Bowel Syndrome-Diarrhea Without Bile Acid Malabsorption. Clin Gastroenterol Hepatol (2017) 15:720-727 e1. doi: 10.1016/j.cgh.2016.11.012

146. Wienbeck M, Karaus M. The Effects of Deoxycholic and Ricinoleic Acid on the Isolated Circular Muscle of the Cat Colon are Modified by LeucineEnkephalin. Z Gastroenterol (1983) 21:365-72.

147. Flynn M, Hammond P, Darby C, Taylor I. Effects of Bile Acids on Human Colonic Motor Function In Vitro. Digestion (1982) 23:211-6. doi: 10.1159/ 000198729

148. Shiff SJ, Soloway RD, Snape WJJr. Mechanism of Deoxycholic Acid Stimulation of the Rabbit Colon. J Clin Invest (1982) 69:985-92. doi: $10.1172 / J C I 110538$

149. Li WT, Luo QQ, Wang B, Chen X, Yan XJ, Qiu HY, et al. Bile Acids Induce Visceral Hypersensitivity via Mucosal Mast Cell-to-Nociceptor Signaling That Involves the Farnesoid X Receptor/Nerve Growth Factor/Transient Receptor Potential Vanilloid 1 Axis. FASEB J (2019) 33:2435-50. doi: 10.1096/fj.201800935RR

150. Akbar A, Yiangou Y, Facer P, Walters JR, Anand P, Ghosh S. Increased Capsaicin Receptor TRPV1-Expressing Sensory Fibres in Irritable Bowel Syndrome and Their Correlation With Abdominal Pain. Gut (2008) 57:9239. doi: $10.1136 /$ gut.2007.138982

151. Barbara G, Stanghellini V, De Giorgio R, Cremon C, Cottrell GS, Santini D, et al. Activated Mast Cells in Proximity to Colonic Nerves Correlate With Abdominal Pain in Irritable Bowel Syndrome. Gastroenterology (2004) 126:693-702. doi: 10.1053/j.gastro.2003.11.055

152. Edwards CA, Brown S, Baxter AJ, Bannister JJ, Read NW. Effect of Bile Acid on Anorectal Function in Man. Gut (1989) 30:383-6. doi: 10.1136/gut.30.3.383

153. Bampton PA, Dinning PG, Kennedy ML, Lubowski DZ, Cook IJ. The Proximal Colonic Motor Response to Rectal Mechanical and Chemical Stimulation. Am J Physiol Gastrointest Liver Physiol (2002) 282:G443-9. doi: 10.1152/ajpgi.00194.2001

Conflict of Interest: The authors declare that the research was conducted in the absence of any commercial or financial relationships that could be construed as a potential conflict of interest.

The reviewer VC declared a shared affiliation with the authors to the handling editor at time of review.

Publisher's Note: All claims expressed in this article are solely those of the authors and do not necessarily represent those of their affiliated organizations, or those of the publisher, the editors and the reviewers. Any product that may be evaluated in this article, or claim that may be made by its manufacturer, is not guaranteed or endorsed by the publisher.

Copyright (๑) 2021 Ní Dhonnabháin, Xiao and O'Malley. This is an open-access article distributed under the terms of the Creative Commons Attribution License (CC BY). The use, distribution or reproduction in other forums is permitted, provided the original author(s) and the copyright owner(s) are credited and that the original publication in this journal is cited, in accordance with accepted academic practice. No use, distribution or reproduction is permitted which does not comply with these terms. 